
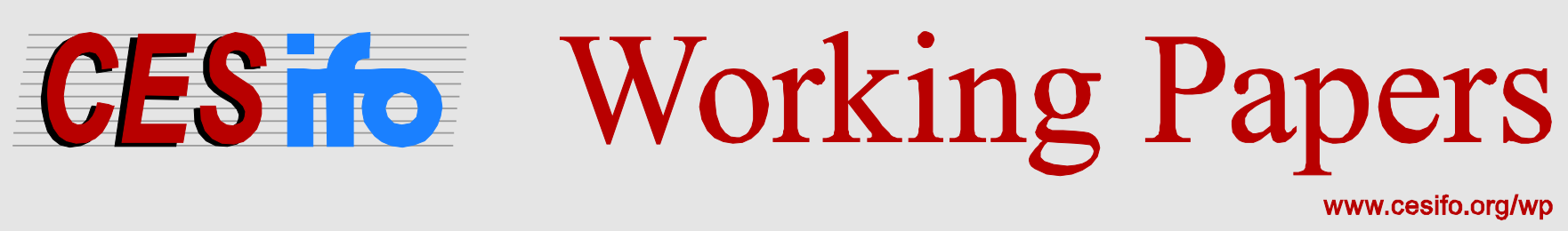

\title{
How to Handle the Crisis in Greece? Empirical Evidence Based on a Survey of Economics Experts
}

\author{
Niklas Potrafke \\ Markus Reischmann
}

CESIFO WORKING PAPER NO. 5860

CATEGORY 1: PUBLIC FinANCE

APRIL 2016

An electronic version of the paper may be downloaded

- from the SSRN website:

- from the RePEc website:

- from the CESifo website:

wWw.SSRN.com

www.RePEc.org

www.CESifo-group.org/wp 


\title{
How to Handle the Crisis in Greece? Empirical Evidence Based on a Survey of Economics Experts
}

\begin{abstract}
We asked experts from 113 countries polled by the CESifo World Economic Survey for their opinions on how to handle the crisis in Greece. $61.9 \%$ of the experts surveyed were not in favour of Greece exiting the Eurozone in the course of the negotiations held in June and July 2015. However, experts in countries such as Germany, the United Kingdom, Sweden, the Czech Republic, Denmark, and Slovakia were in favour of Greece exiting the Eurozone. The share of experts who were in favour of Greece staying in the Eurozone increased to $69.8 \%$ in October 2015. 72.4\% of experts surveyed believed that the IMF should provide credit to Greece and 83.6\% stated that the IMF should engage in economic reform programmes. Econometric evidence shows that experts from those Eurozone countries with high public debt-to-GDP-ratios were less likely to support the Grexit: when the debt-to-GDP-ratio increased by one percentage point, the likelihood of survey participants favouring the Grexit decreased by around 0.35 percentage points. Support for IMF reforms, by contrast, proved far less controversial.
\end{abstract}

JEL-Codes: H630, C830, H120, F530, E420, F450.

Keywords: Greece, Grexit, experts’ survey, public debt crisis, IMF, international organisations.

Niklas Potrafke

Ifo Institute - Leibniz Institute for

Economic Research

at the University of Munich

Poschingerstrasse 5

Germany-81679 Munich

potrafke@ifo.de
Markus Reischmann

Ifo Institute - Leibniz Institute for

Economic Research

at the University of Munich

Poschingerstrasse 5

Germany-81679 Munich

reischmann@ifo.de

April 2016

We would like to thank Stefan Homburg, Athanassios Pitsoulis, Holger Schmieding, Günther Schulze, Richard Salsmann, Hans-Werner Sinn, and the participants of the Munich Country Risk Forum (Munich 2016) and Public Choice Society Meetings (Fort Lauderdale 2016) for their helpful comments and Lisa Giani-Contini for proof-reading. 


\section{Introduction}

Should Greece exit the European Monetary Union (Grexit)? Commentators disagree. At the end of July 2015, European governments, the European Central Bank (ECB) and the International Monetary Fund (IMF) provided a new bailout package for Greece and decided against the Grexit. ${ }^{3}$ Opinion polls on citizens' beliefs, however, showed that citizens in countries such as Denmark, Sweden, the United Kingdom and especially Finland were in favour of the Grexit. ${ }^{4}$ In France and Norway, opponents and advocates of the Grexit were split fifty-fifty. When the preferences of politicians (and the policies that they pursue) are not aligned with voters’ preferences, political principal-agent problems arise.

Sinn (2015) describes that Greece's major problem is its lack of competitiveness. The prices of goods and services do not match their productivity. To overcome its crisis, Greece needs to become more competitive compared to other European countries. ${ }^{5}$ Sinn (2015: 24 f.) describes four options on how to deal with Greece's lack of competitiveness: (1) The other European countries may accept Greece's lack of competitiveness and continue to financially support Greece. In the long run, however, that is quite unlikely to happen. (2) Greece internally deflates by slashing prices. That is also quite unlikely to occur because drastic price cuts would give rise to bankruptcies, severe problems with tenants who are bound by longterm contracts, and revolts on the part of trade unions. (3) The northern European countries inflate. It is not conceivable that countries such as Germany would accept inflation of, for example, $50 \%$ over a ten-year period. Moreover, it is not quite clear how to induce drastic inflation in the northern European countries. The ECB's quantitative easing programmes, for

\footnotetext{
${ }^{3}$ Pitsoulis and Schwuchow (2015) elaborate on the bailout negotiations. On the economic and political developments in Greece before 2015 see for example Hodson (2015) and Katsimi and Moutos (2010).

4 YouGov Survey Results 23-29 July 2015 (https://d25d2506sfb94s.cloudfront.net/cumulus uploads/document/nrxyjk0jmj/Eurotrack July Website Gr eece.pdf, accessed on 23 March 2016).

${ }^{5}$ Greece also needs to implement structural reforms to increase economic growth and budget surpluses. Greece has a large shadow economy (see, e.g., Berger et al. 2014, Schneider 2015), high military spending (see, e.g., Antonakis 1997), and an inefficient public administration.
} 
instance, have not given rise to the desired increases in inflation. ${ }^{6}$ (4) Greece leaves the European Monetary Union and introduces its own currency by, for example, returning to the drachma (Grexit). The drachma is expected to devalue compared to the euro. Introducing the drachma and freely floating exchange rates may also bring an end to cease the capital flights. ${ }^{7}$ The devaluation is likely to attract fresh private capital. The sharp rise in the price of imported goods would boost domestic production and lower unemployment. Thanks to its fertile soils and favourable climatic conditions, Greece has comparative advantages in the agriculture and tourism sectors that may well be exploited. Indeed, Sinn (2015: 28) maintains that: "It is likely that the entire Greek economy would perk up after exiting the currency union.”

A Grexit would certainly have disadvantages. Commentators have emphasized the potential disadvantages of a Grexit in order to prevent it. They argue that a devaluation of the drachma would increase import prices and lower the living standards of Greece’s population. Rising import prices are also likely to give rise to shortages of key import products such as medicines and energy. Clearly, the governments of other European countries would need to help with essential goods. Other commentators oppose the Grexit for geopolitical reasons, fearing that Greece would subsequently form an alliance with Russia. Greece is currently a member state of the North Atlantic Treaty Organization (NATO). Opponents of the Grexit maintain that Greece would leave the Eurozone and NATO. After leaving the Eurozone Greece would also lack an instrument with which to exert pressure on international money lenders. It is unclear whether the lack of such a menace would prove a disadvantage for Greece in the long term. ${ }^{8}$

\footnotetext{
${ }^{6}$ Homburg (2015) describes the consequences of quantitative easing in Japan.

${ }^{7}$ On capital flights in the course of the subprime crisis and the Greek crisis see, for example, Sinn (2014, 2015), Sinn and Wollmershäuser (2012), and Potrafke and Reischmann (2014).

${ }^{8}$ Schmieding (2016) elaborates on the future of the Eurozone.
} 
The IMF has provided substantial credit to Greece and, as a member of the "Troika", it has also participated in Greece's economic reform programmes. By engaging in the bailout programmes for Greece, the IMF has softened the criteria on borrowing, which usually correspond to the quotas (capital shares) of member states in the IMF. ${ }^{9}$ Emerging market countries are likely to criticize that the IMF has focused excessively on Europe and that its lending operations in European countries appear overly generous. ${ }^{10}$

In October 2015, we asked economics experts from 113 countries for their opinions on how to handle the crisis in Greece via a special question in the CESifo World Economic Survey (WES). The majority of experts surveyed (61.9\%) was not in favour of Greece exiting the Eurozone in the course of the negotiations held in June and July 2015. Distinguishing between responses from experts based in the Eurozone and in the rest of the world reveals no difference concerning the share of participants that approves of Greece staying in the Eurozone. However, experts in countries such as Germany, the United Kingdom, Sweden, the Czech Republic, Denmark, and Slovakia were in favour of Greece exiting the Eurozone. When the experts were asked about their position after the negotiations had taken place, the share of experts in favour of Greece remaining in the Eurozone increased to $69.8 \%$. This share was even higher among those experts based in Eurozone countries (72.3\%).

Econometric evidence shows that experts from Eurozone countries with high public debt-to-GDP-ratios were less likely to advocate the Grexit. In cases where the debt-to-GDPratio increased by one percentage point, the likelihood of survey participants favouring the Grexit decreased by about 0.35 percentage points. In other words, when the debt-to-GDPratio increased by one standard deviation (32.41 percent of GDP), the likelihood of survey participants favouring the Grexit decreased by about 11.2 percentage points.

\footnotetext{
${ }^{9}$ On IMF quotas, capital shares and lending decisions see, for example, Moser and Sturm (2011). On IMF conditionality see Dreher (2009) and Dreher and Vaubel (2004).

${ }^{10}$ Bird et al. (2015) describe determinants influencing the engagement of the IMF in a country.
} 
72.4\% of experts surveyed stated that the IMF should provide credit to Greece and 83.6\% declared that the IMF should engage in economic reform programmes. The share of experts inside the Eurozone who agreed with the statement that the IMF should provide credit was marginally higher at 0.5 percentage points (72.9\%). The share of experts inside the Eurozone who agreed with the statement that the IMF should engage in economic reform programmes in Greece was 2.1 percentage points higher (85.7\%).

\section{Descriptive statistics}

In October 2015, we asked WES economics experts from 113 countries for their opinion on how to handle the crisis in Greece. The survey featured four questions: in the first question we asked whether the experts surveyed advocated the Grexit in the course of the negotiations in summer 2015 ("Were you in favour of Greece exiting the Eurozone in the course of the negotiations in June/July 2015”). We also asked the experts about their position in October 2015, after the negotiations had taken place, whether "Greece should exit the Eurozone”.

Figure 1 shows the experts' answers to the question of whether Greece should have left the Eurozone in the course of the negotiations held in June/July 2015. 540 out of 872 experts (61.9\%) were not in favour of Greece exiting the Eurozone. When WES experts were asked about their position after the negotiations had taken place, the number of experts in favour of Greece remaining in the Eurozone increased to 606 out of 868 (69.8\%).

Around $10 \%$ of the experts come from associations and chambers, 3\% from central banks, $12 \%$ from banks and other financial institutions, 27\% from non-financial companies, 5\% from national ministries and agencies, 3\% from embassies, consulates, and other foreign agencies, 2\% from international organizations, 31\% from research institutes, think tanks, and universities, and 5\% from other institutions (see Table 1). Figure 2 shows the answers to the questions on the Grexit by expert type. The majority of all expert groups, except for experts 
from embassies, consulates and other foreign agencies, was not in favour of Greece exiting the Eurozone in June/July and October 2015.

In the European countries, the majority of experts was in favour of Greece exiting the Eurozone in June/July 2015 in Germany, the United Kingdom, Sweden, the Czech Republic, Denmark, and Slovakia. ${ }^{11}$ Figure 3 shows responses to the questions on the Grexit by country. In countries presented in orange, for example, the share of experts favouring a Grexit was between 0.5 and 0.75 . When the experts were asked about their position after the negotiations had taken place, the majority of experts in the United Kingdom, Denmark, Slovakia, and the Czech Republic was still in favour of Greece exiting the Eurozone. ${ }^{12}$ In the GIIPSC countries (Greece, Italy, Ireland, Portugal, Spain and Cyprus) the share of experts advocating the Grexit was particularly low. In Greece and Cyprus, no expert advocated a Grexit in June/July and in October 2015; in Ireland 25.0\% of the experts were in favour of a Grexit in June/July (0\% in October); while in Italy 27.2\% (19.0\%), in Portugal 36.4\% (30.8\%), and in Spain 37.1\% (24.2\%) expressed their support of a Grexit.

We also asked the experts whether "the IMF should provide credit to Greece", and if "the IMF should engage in the economic reform programme in Greece". Figure 4 shows the experts' answers on these two issues. 616 out of 851 experts (72.4\%) advocated that the IMF should provide credit to Greece and 716 out of 856 experts (83.6\%) stated that the IMF should engage in the economic reform programmes in Greece. The majority of all expert groups was in favour of the IMF providing credit to Greece and engaging in economic reform programmes (Figure 5). In Egypt, Kazakhstan, Bulgaria and Zimbabwe, by contrast, the majority of experts was not in favour of the IMF providing credit to Greece (Figure 6). In

\footnotetext{
${ }^{11}$ The other countries, where the majority of experts was in favour of a Grexit in June/July 2015, are India, Russia, China, the Philippines, Togo, Thailand, the United Arab Emirates, Chile, Egypt, Venezuela, Angola, Vietnam, Tunisia, Burundi, and Lebanon.

${ }^{12}$ The other countries, where the majority of experts was in favour of the Grexit in October 2015, were Chile, Egypt, the Philippines, Togo, Comoros, Congo, Lebanon, Tunisia and Angola.
} 
Lebanon, Bangladesh, Algeria, Tunisia, and Trinidad and Tobago the majority of experts was not in favour of the IMF engaging in the economic reform programmes in Greece.

\section{Econometric analysis}

\subsection{Empirical specification}

A topical question is whether economic conditions in individual countries influence their inhabitants' opinions on the negotiations over a bailout programme for Greece. To examine the nexus between economic conditions in an individual country and the response behaviour of the experts, we estimate an econometric model. The baseline regression model has the following form:

$$
\begin{aligned}
& \text { Answer }_{\mathrm{ij}}=\alpha_{\mathrm{j}}+\beta_{\mathrm{j}} \text { Debt }_{\mathrm{i}}+\gamma_{\mathrm{j}} \text { Primary Surplus }_{\mathrm{i}}+\delta_{\mathrm{j}} \text { Income Group }_{i}+\varepsilon_{\mathrm{j}} \text { Economic } \\
& \text { Freedom }_{\mathrm{i}}+\Sigma_{\mathrm{k}} \zeta_{\mathrm{kj}} \text { Expert type }_{\mathrm{k} i}+u_{\mathrm{ij}},
\end{aligned}
$$

where the dependent variable Answer ${ }_{\mathrm{ij}}$ assumes the value 0 if expert $i$ answered "no" to question $j$ and 1 if expert $i$ answered "yes" to question $j(j \in[1,4])$. Debt $t_{\mathrm{i}}$ is our main explanatory variable and describes the debt-to-GDP ratio. We include control variables. Primary Surplus $\mathrm{i}_{\mathrm{i}}$ is the primary surplus-to-GDP ratio. We use 5-year averages over the period 2011-2015 for the variables Debt, Primary Surplus. Economic Freedom Fis $_{\mathrm{i}}$ the Economic Freedom Index (Gwartney et al. 2015) of the country of expert i. Income Group takes on values from 1 to 3 depending on whether expert $i$ was based in a country with (1) high, (2) medium or (3) low income. Expert type $e_{k i}$ describes the type of experts (see section 2). ${ }^{13}$ There are no other personal characteristics of the experts available, such as political preferences that are likely to predict individual responses (European citizens favouring left-

\footnotetext{
${ }^{13}$ The reference category is "research institutes, think tanks, and universities”.
} 
wing political parties have been shown, for example, not to support the Grexit - see Bansak et al. 2016).

We expect experts from countries with high debt-to-GDP ratios not to favour the Grexit. ${ }^{14}$ In Europe, the governments of many countries took advantage of the low interest rates after the introduction of the euro to engage in excessive borrowing. When a country exits the Eurozone, it loses the favourable borrowing conditions and interest rates increase. When a country exits the Eurozone and devalues its currency, the face value of its debt denominated in euro also increases. If Greece were to exit the Eurozone, other countries that lack competitiveness may also be forced into exiting.

We estimate the regression model for the full sample and a Eurozone sample. When we use the Eurozone sample, the variable Income Group is not included as an explanatory variable, because all Eurozone countries are high-income countries.

We estimate a probit model with standard errors robust to heteroskedasticity (Huber/White/sandwich standard errors - see Huber 1967, White 1980 and 1982, and Stock and Watson 2008). Table 1 and Table 2 show descriptive statistics, while Table 3 and Table 4 show the correlations between the variables.

\subsection{Results}

Table 5 shows the results when we use the question about the Grexit in June/July 2015 as a dependent variable. We estimate the model including and excluding the control variables on economic conditions because the control variables are correlated with the debt-to-GDP ratio (Tables 3 and 4). Using answers from experts from all countries, the results show that experts

\footnotetext{
${ }^{14}$ Gärtner (1997) shows that people in countries with looser fiscal policy, i.e. higher debt, were more in favor of introducing the Euro. On a critique of the introduction of the Euro see Homburg (1997).
} 
from countries with high public debt and low income were more likely not to advocate that Greece should have left the Eurozone in June/July 2015 (column 2 in Table 5). The debt-toGDP ratio and the income group variable are statistically significant at the 5\% level. Experts from associations and chambers were about 21 percentage points more likely to advocate that Greece should have left the Eurozone in June/July 2015 than experts from research institutes - the dummy variables being statistically significant at the 5\% level (column 2 in Table 5).

Focusing on Eurozone countries, the results show that experts from countries with high debt-to-GDP ratios were less likely to advocate the Grexit (column 4 in Table 5). When the debt-to-GDP-ratio increased by one percentage point, the likelihood of survey participants favouring the Grexit decreased by about 0.35 percentage points. In other words, when the debt-to-GDP-ratio increased by one standard deviation (32.41 percent of GDP), the likelihood of experts favouring the Grexit decreased by about 11.2 percentage points - an effect being statistically significant at the $1 \%$ level. The fact that experts from high debt countries were opposed to the Grexit indicates that they either did not believe that their countries should bite the hand that feeds them or that they felt solidarity with Greece.

Asked about whether Greece should leave the Eurozone in October 2015, experts from countries with high debt-to-GDP ratios were less likely to advocate the Grexit in the full sample (column 2 in Table 6). Experts from central banks were more likely not to advocate that Greece should exit the Eurozone in October 2015 than experts from research institutes (column 2 in Table 6).

When we restrict the sample to Eurozone countries, the results also show that experts from countries with high debt-to-GDP ratios were less likely to advocate the Grexit in October 2015 (column 4 in Table 6). Experts from countries with high primary budget 
surpluses were more likely to advocate that Greece should have left the Eurozone in October 2015 (column 4 in Table 6).

Using the question on whether the IMF should provide credit to Greece as the dependent variable for the full sample, none of the explanatory variables describing economic conditions turns out to be statistically significant (column 2 in Table 7). Focusing on Eurozone countries, the results show that experts from countries with high debt-to-GDP ratios were somewhat more likely to advocate that the IMF should provide credit to Greece, an effect being statistically significant at the 10\% level (column 4 in Table 7). However, this effect lacks statistical significance when excluding either Finland, Germany, Greece, Ireland, Portugal or Slovakia.

Experts from countries with high primary budget surpluses and high economic freedom appeared to be somewhat more likely to advocate that the IMF should engage in the economic reform programmes. In cases where the primary surplus-to-GDP ratio increased by one percentage point, the likelihood of advocating that the IMF should engage in the reform programs rose by one percentage point (column 2 in Table 8). When the Economic Freedom Index increased by one point, the likelihood of advocating that the IMF should engage in the reform programmes increased by 4.0 percentage points (column 2 in Table 8 ). However, the primary surplus-to-GDP ratio and the Economic Freedom Index are only statistically significant at the $10 \%$ level in column (2) in Table 8 . Restricting the sample to Eurozone countries, none of the variables turns out to be statistically significant (column 4 Table 8).

\subsection{Robustness tests}

In our baseline specification we use the answers of every individual expert as the dependent variable. As a robustness test we employ a cross-sectional specification where the dependent 
variable is the share of experts that answered "yes" to the individual questions. We estimate the model by Ordinary Least Squares (OLS). The results corroborate our findings on the individual expert level.

We have examined whether inferences change when we include/exclude individual countries. The results in Tables 5 and 7 are not sensitive to including/excluding individual countries. When we exclude either Greece, Ireland or Slovakia from the Eurozone sample, the coefficient of the debt-to-GDP ratio lacks statistical significance in column (4) in Table 6. When we exclude either Germany, Ireland or Slovakia from the Eurozone sample, the coefficient of the primary surplus-to-GDP ratio lacks statistical significance in column (4) in Table 6. When either Portugal, the United Kingdom, Norway or Belgium are excluded from the full sample, the coefficient of the primary surplus-to-GDP ratio lacks statistical significance in column (2) in Table 8. The coefficient of the Economic Freedom Index lacks statistical significance when we exclude countries such as Switzerland, Spain or Canada from the full sample (column 2 in Table 8). We thus cannot conclude that either the debt-to-GDP ratio, the primary surplus-to-GDP ratio, the income group the experts belong to or the Economic Freedom Index in an expert's country predicted whether the IMF should be active in Greece.

\section{Conclusion}

By using the CESifo World Economic Survey we examined economics experts' views on how to handle the economic crisis in Greece and investigated the factors predicting their views. In June/July 2015, 61.9\% of the experts surveyed were in favour of a Grexit (69.8\% in October 2015). The results show that experts from Eurozone countries with high public debtto-GDP-ratios were especially not in favour of the Grexit. To be sure, the bailout that politicians agreed to in July 2015 gave rise to more transfers and the socialization of Greek 
public debt. Experts who fear that their own country will need bailout packages seem to be more likely to advocate bailout policies that may well benefit their own countries in the near future. In other words, experts from those Eurozone countries with high debt-to-GDP-ratios opposed the Grexit, which suggests that these experts felt it wiser for their countries not to bite the hand that feeds them, or may have felt solidarity with Greece.

In contrast to experts' views on the Grexit, IMF support for Greece was far less controversial. The purpose of the IMF is to help countries to restore their macroeconomic stability and assist countries in effectively managing their economies. Indeed, many experts agreed that the IMF should engage in economic reform programmes and provide credit to Greece. 


\section{References}

Antonakis, N. (1997). Military Expenditure and Economic Growth in Greece, 1960-90. Journal of Peace Research 34, 89-100

Bansak, K., M. M. Bechtel, J. Hainmueller, and J. Margalit (2015). The ideological bias of the Grexit debate. Stanford University Graduate School of Business Research Paper No. 16-9.

Berger, W., M. Pickhardt, A. Pitsoulis, A. Prinz, and J. Sarda (2014). The hard shadow of the Greek economy: New estimates of the size of the underground economy and its fiscal impact. Applied Economics 46, 2190-2204.

Bird, G., J. Mylonas, and D. Rowlands (2015). The political economy of participation in IMF programs: a disaggregated empirical analysis. Journal of Economic Policy Reform 18, 221-243.

Dreher, A. (2009). IMF conditionality: Theory and evidence. Public Choice 141, 233-267.

Dreher, A., and R. Vaubel (2004). The causes and consequences of IMF conditionality. Emerging Markets Finance and Trade 40, 26-54.

Gärtner M. (1997). Who wants the euro - and why? Economic explanations of public attitudes towards a single European currency. Public Choice 93, 487-510.

Gwartney, J., R. Lawson, and J. Hall (2015). Economic Freedom of the World: 2015 Annual Report. Fraser Institute.

Hodson, D. (2015). Eurozone governance: Deflation, Grexit 2.0 and the second coming of Jean-Claude Juncker. Journal of Common Market Studies 53, 144-161.

Homburg, S. (1997). Why democracy is essential to monetary stability - and why EMU will have neither. The European Journal, June 1997, p. 13.

Homburg, S. (2015). Understanding benign liquidity traps: The case of Japan. Hannover Economic Papers (HEP) dp 557.

Huber, P. J. (1967). The behavior of maximum likelihood estimates under nonstandard conditions. In Proceedings of the Fifth Berkeley Symposium on Mathematical Statistics and Probability, Volume 1: Statistics, edited by Lucien M. Le Cam and Jerzey Neyman, pp. 221-233. Berkeley, CA: University of California Press.

Katsimi, M., and T. Moutos (2010). EMU and the Geek crisis: The political-economy perspective. European Journal of Political Economy 26, 568-576. 
Moser, C., and J.-E. Sturm (2011). Explaining IMF lending decisions after the Cold War. Review of International Organizations 6, 307-340.

Pitsoulis, A., and S. C. Schwuchow (2015). Holding out for a better deal: Brinkmanship in the Greek bailout negotiations. MPRA Paper No. 68291.

Potrafke, N., and M. Reischmann (2014). Explosive Target balances of the German Bundesbank. Economic Modelling 42, 439-444.

Schmieding, H. (2016). Searching for the lender of last resort. International Economics and Economic Policy 13, 161-176.

Schneider, F. (2015). Size and development of the shadow economy of 31 European and 5 other OECD countries from 2003 to 2015: Different developments, mimeo.

Sinn, H.-W. (2014). The Euro Trap. On bursting bubbles, budgets and beliefs, Oxford Universtiy Press, Oxford.

Sinn, H.-W. (2015). The Greek tragedy. CESifo Forum 16 Special Issue 2015 (June), 5-35.

Sinn, H.-W., and T. Wollmershäuser (2012). Target loans, current account balances and capital flows: the ECB's rescue facility. International Tax and Public Finance 19, 468508.

Stock, J. H., and M. W. Watson (2008). Heteroskedasticity-robust standard errors for fixed effect panel data regression. Econometrica 76, 155-174.

White, H. (1980). A heteroskedasticity-consistent covariance matrix estimator and a direct test for heteroskedasticity. Econometrica 48, 817-838.

White, H. (1982) Maximum likelihood estimation of misspecified models. Econometrica 50, $1-25$. 
Figure 1: Should Greece exit the euro zone? (answers total)
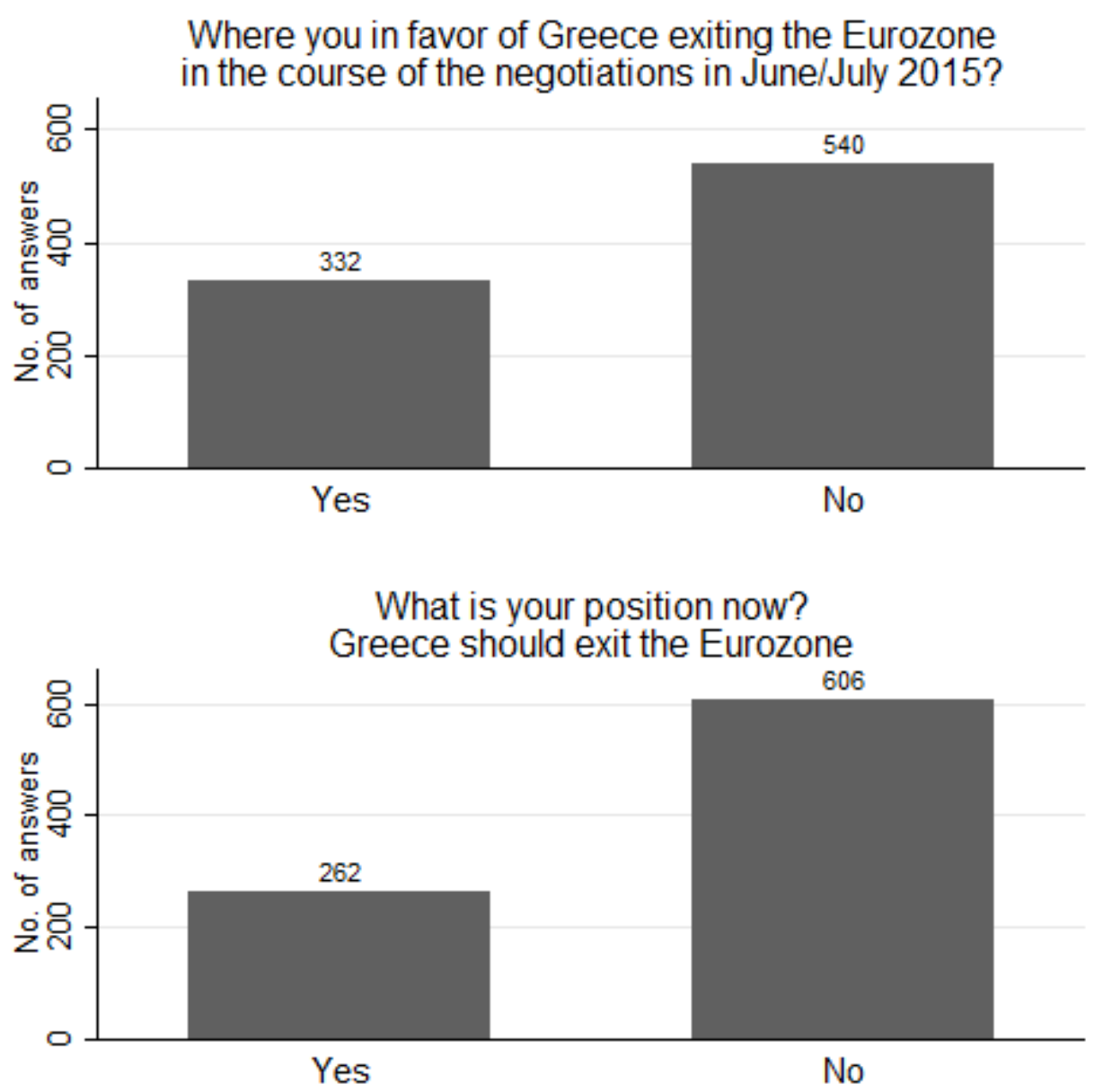

Source: Ifo World Economic Survey (WES) IV/2015. 
Figure 2: Should Greece exit the euro zone? (answers by expert type)
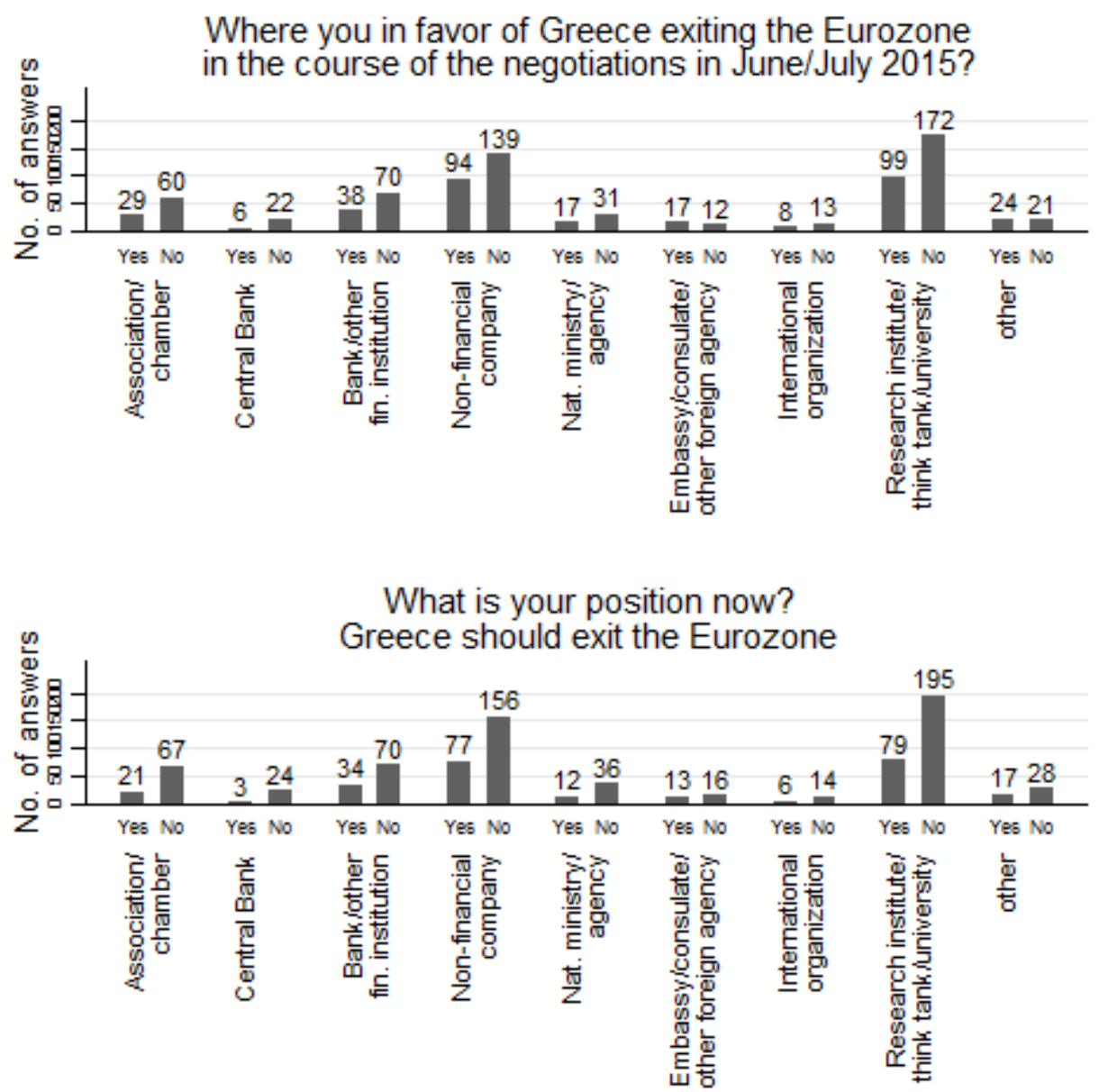

Source: Ifo World Economic Survey (WES) IV/2015 
Figure 3: Should Greece exit the euro zone? (answers by countries)

Share of experts that were in favor of Greece exiting the Eurozone in the course of the negotiations in June/July 2015

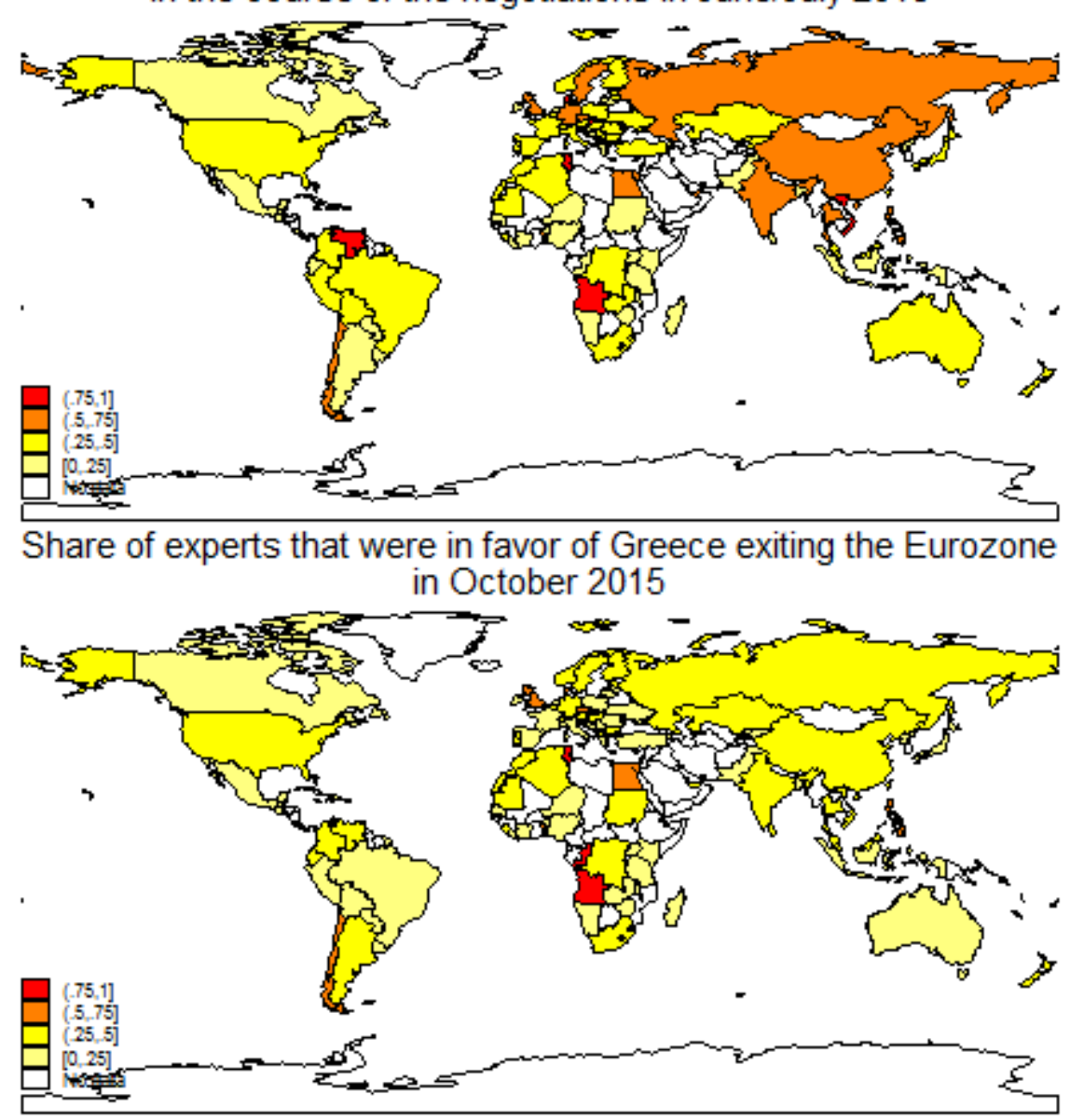

Source: Ifo World Economic Survey (WES) IV/2015 
Figure 4: Should the IMF engage in Greece (answers total)

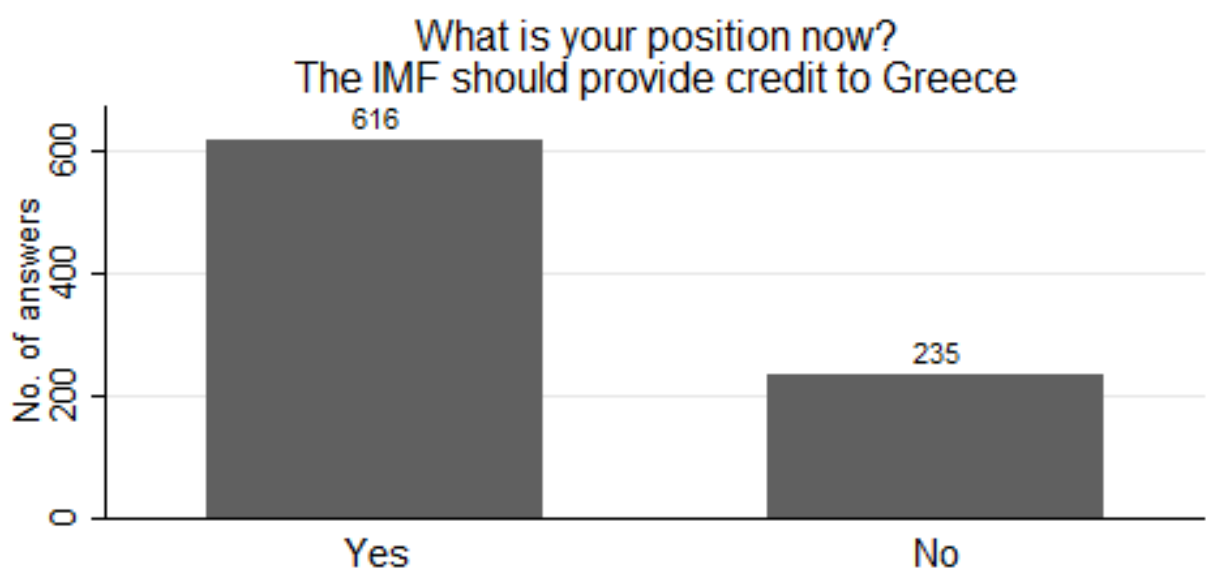

What is your position now?

The IMF should engage in the economic reform programs in Greece

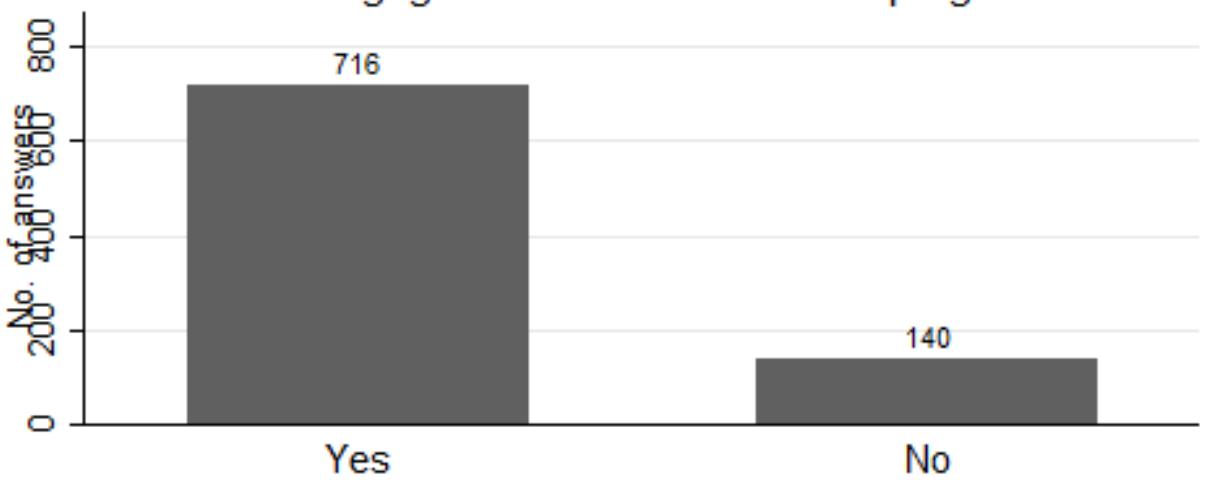

Source: Ifo World Economic Survey (WES) IV/2015 
Figure 5: Should the IMF engage in Greece? (answers by expert groups)

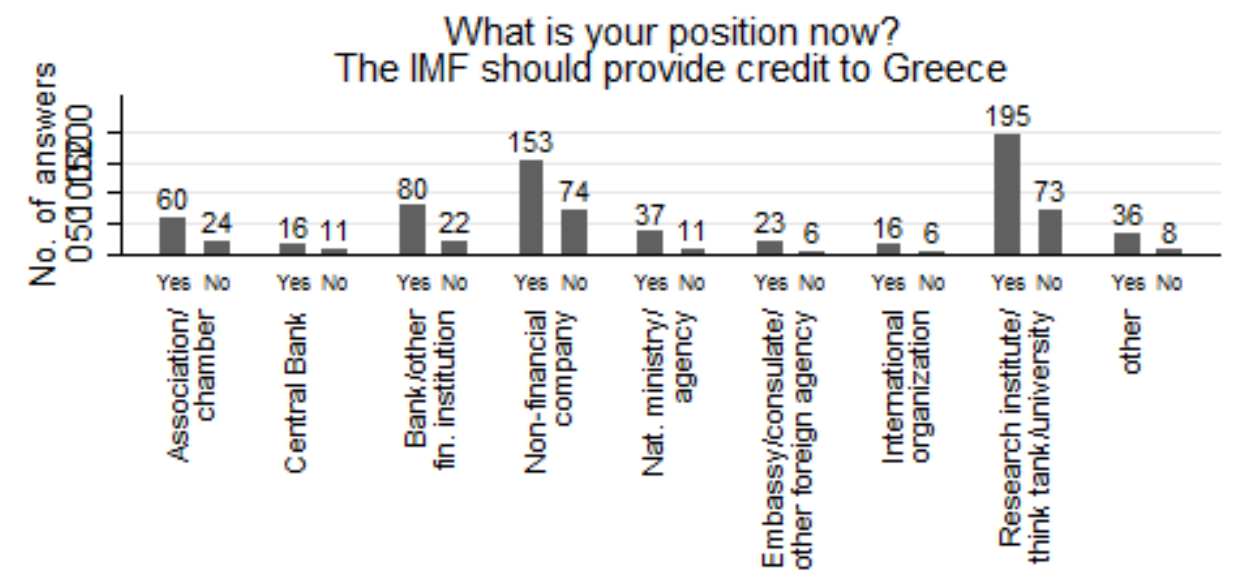

What is your position now?

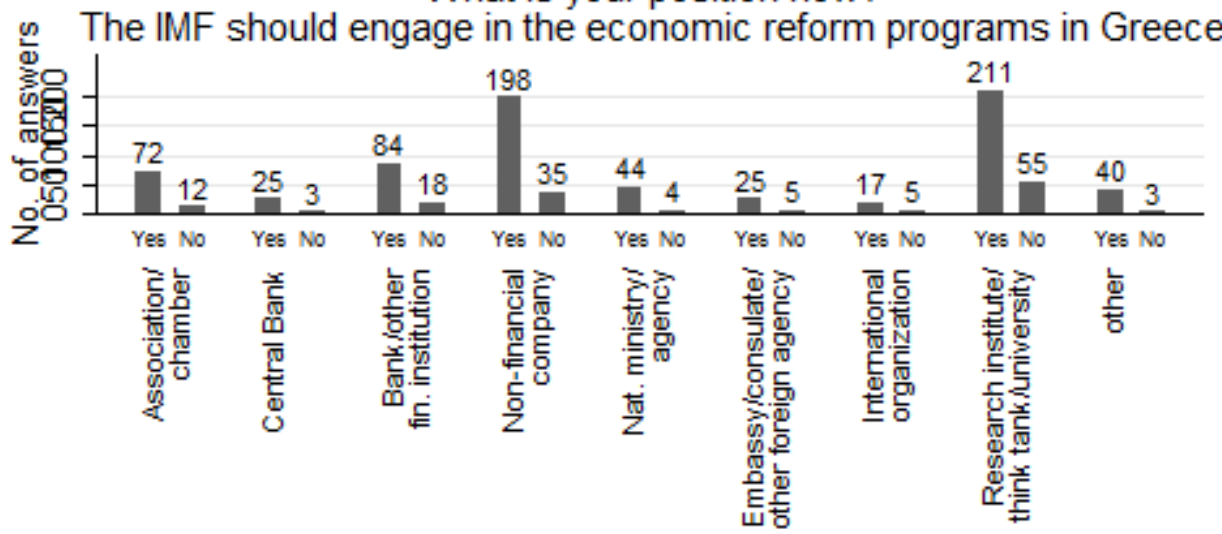

Source: Ifo World Economic Survey (WES) IV/2015 
Figure 6: Should the IMF engage in Greece? (answers by countries)

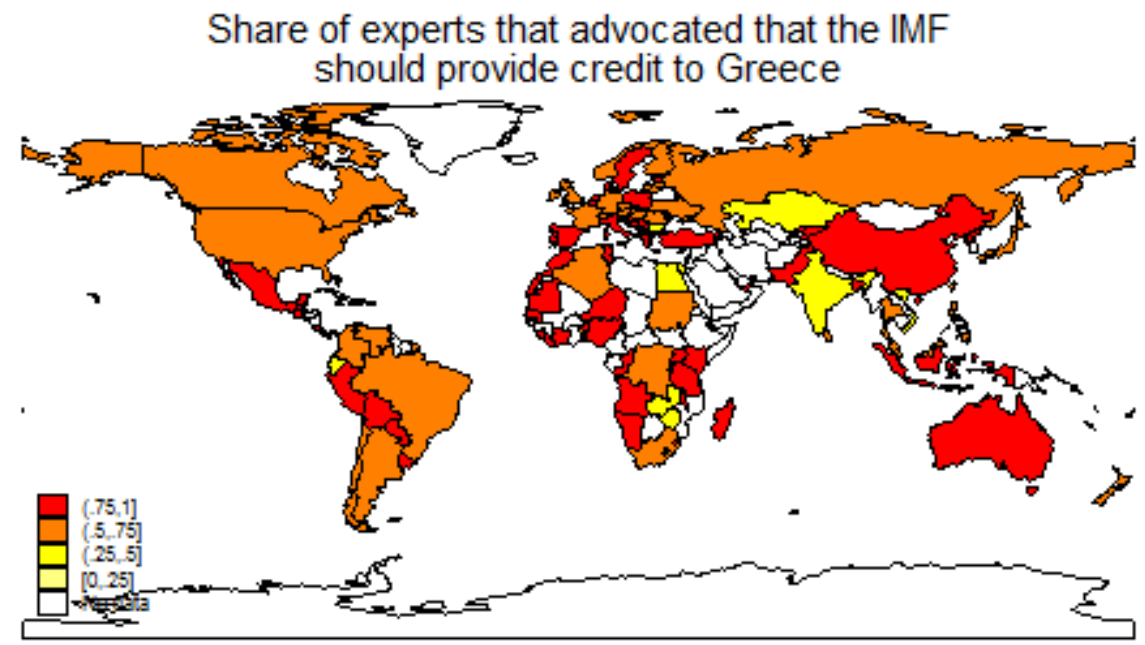

Share of experts that advocated that the IMF should engage in the economic reform programs in Greece

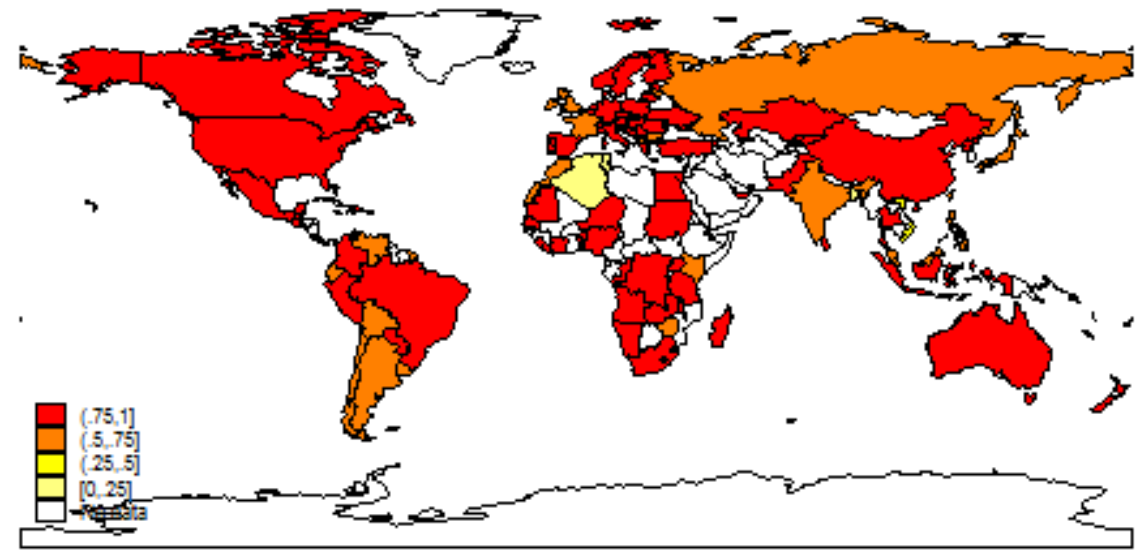

Source: Ifo World Economic Survey (WES) IV/2015 
Table 1: Descriptive statistics (full sample)

\begin{tabular}{|c|c|c|c|c|c|c|}
\hline Variable & Mean & Std. Dev. & Min & Max & Obs & Source \\
\hline Q1: Grexit in June & 0.38 & 0.49 & 0 & 1 & 872 & $\begin{array}{l}\text { CESifo World Economic Survey } \\
\text { November } 2015\end{array}$ \\
\hline Q2: Grexit in October & 0.30 & 0.46 & 0 & 1 & 868 & $\begin{array}{l}\text { CESifo World Economic Survey } \\
\text { November } 2015\end{array}$ \\
\hline Q3: IMF credit & 0.72 & 0.45 & 0 & 1 & 851 & $\begin{array}{l}\text { CESifo World Economic Survey } \\
\text { November } 2015\end{array}$ \\
\hline Q4: IMF reforms & 0.84 & 0.37 & 0 & 1 & 856 & $\begin{array}{l}\text { CESifo World Economic Survey } \\
\text { November } 2015\end{array}$ \\
\hline Debt-to-gdp & 64.20 & 43.83 & 0.37 & 240.20 & 885 & $\begin{array}{l}\text { IMF World Economic Outlook } \\
\text { October } 2015\end{array}$ \\
\hline Primary Surplus-to-GDP & -1.39 & 2.46 & -13.48 & 8.52 & 859 & $\begin{array}{l}\text { IMF World Economic Outlook } \\
\text { October } 2015\end{array}$ \\
\hline EF Index & 7.08 & 0.69 & 3.23 & 8.97 & 874 & $\begin{array}{l}\text { Fraser Insitute Economic Freedom } \\
\text { of the World } 2015 \text { Annual Report, } \\
\text { Gwartney et al. (2015) }\end{array}$ \\
\hline Income Group & 1.43 & 0.57 & 1 & 3 & 889 & $\begin{array}{l}\text { CESifo World Economic Survey } \\
\text { November } 2015\end{array}$ \\
\hline \multicolumn{7}{|l|}{ Affiliation } \\
\hline Association/Chamber & 0.10 & 0.30 & 0 & 1 & 889 & $\begin{array}{l}\text { CESifo World Economic Survey } \\
\text { November } 2015\end{array}$ \\
\hline Central Bank & 0.03 & 0.18 & 0 & 1 & 889 & $\begin{array}{l}\text { CESifo World Economic Survey } \\
\text { November } 2015\end{array}$ \\
\hline Financial institution & 0.12 & 0.33 & 0 & 1 & 889 & $\begin{array}{l}\text { CESifo World Economic Survey } \\
\text { November } 2015\end{array}$ \\
\hline Non-fin. company & 0.27 & 0.44 & 0 & 1 & 889 & $\begin{array}{l}\text { CESifo World Economic Survey } \\
\text { November } 2015\end{array}$ \\
\hline Nat. ministry /agency & 0.05 & 0.23 & 0 & 1 & 889 & $\begin{array}{l}\text { CESifo World Economic Survey } \\
\text { November } 2015\end{array}$ \\
\hline Embassy/consulate & 0.04 & 0.18 & 0 & 1 & 889 & $\begin{array}{l}\text { CESifo World Economic Survey } \\
\text { November } 2015\end{array}$ \\
\hline Int.organization & 0.03 & 0.16 & 0 & 1 & 889 & $\begin{array}{l}\text { CESifo World Economic Survey } \\
\text { November } 2015\end{array}$ \\
\hline Research institute & 0.31 & 0.46 & 0 & 1 & 889 & $\begin{array}{l}\text { CESifo World Economic Survey } \\
\text { November } 2015\end{array}$ \\
\hline Other institutions & 0.05 & 0.22 & 0 & 1 & 889 & $\begin{array}{l}\text { CESifo World Economic Survey } \\
\text { November } 2015\end{array}$ \\
\hline
\end{tabular}


Table 2: Descriptive statistics (Eurozone sample)

\begin{tabular}{|c|c|c|c|c|c|c|}
\hline Variable & Mean & $\begin{array}{l}\text { Std. } \\
\text { Dev. }\end{array}$ & Min & Max & Obs. & Source \\
\hline Q1: Grexit in June & 0.38 & 0.49 & 0 & 1 & 260 & $\begin{array}{l}\text { CESifo World Economic Survey } \\
\text { November } 2015\end{array}$ \\
\hline Q2: Grexit in October & 0.28 & 0.45 & 0 & 1 & 256 & $\begin{array}{l}\text { CESifo World Economic Survey } \\
\text { November } 2015\end{array}$ \\
\hline Q3: IMF credit & 0.73 & 0.45 & 0 & 1 & 251 & $\begin{array}{l}\text { CESifo World Economic Survey } \\
\text { November } 2015\end{array}$ \\
\hline Q4: IMF reforms & 0.86 & 0.35 & 0 & 1 & 252 & $\begin{array}{l}\text { CESifo World Economic Survey } \\
\text { November } 2015\end{array}$ \\
\hline Debt-to-GDP & 85.89 & 32.41 & 9.30 & 175.28 & 260 & $\begin{array}{l}\text { IMF World Economic Outlook October } \\
2015\end{array}$ \\
\hline $\begin{array}{l}\text { Primary Surplus-to- } \\
\text { GDP }\end{array}$ & -1.07 & 2.11 & -4.80 & 1.67 & 260 & $\begin{array}{l}\text { IMF World Economic Outlook October } \\
2015\end{array}$ \\
\hline EF Index & 7.33 & 0.25 & 6.44 & 7.90 & 260 & $\begin{array}{l}\text { Fraser Insitute Economic Freedom of the } \\
\text { World } 2015 \text { Annual Report, Gwartney et } \\
\text { al. (2015) }\end{array}$ \\
\hline \multicolumn{7}{|l|}{ Affiliation } \\
\hline Association/Chamber & 0.12 & 0.32 & 0 & 1 & 260 & $\begin{array}{l}\text { CESifo World Economic Survey } \\
\text { November } 2015\end{array}$ \\
\hline Central Bank & 0.02 & 0.15 & 0 & 1 & 260 & $\begin{array}{l}\text { CESifo World Economic Survey } \\
\text { November } 2015\end{array}$ \\
\hline Financial institution & 0.17 & 0.37 & 0 & 1 & 260 & $\begin{array}{l}\text { CESifo World Economic Survey } \\
\text { November } 2015\end{array}$ \\
\hline Non-fin. company & 0.32 & 0.47 & 0 & 1 & 260 & $\begin{array}{l}\text { CESifo World Economic Survey } \\
\text { November } 2015\end{array}$ \\
\hline Nat. ministry /agency & 0.04 & 0.20 & 0 & 1 & 260 & $\begin{array}{l}\text { CESifo World Economic Survey } \\
\text { November } 2015\end{array}$ \\
\hline Embassy/consulate & 0.02 & 0.14 & 0 & 1 & 260 & $\begin{array}{l}\text { CESifo World Economic Survey } \\
\text { November } 2015\end{array}$ \\
\hline Int.organization & 0.01 & 0.09 & 0 & 1 & 260 & $\begin{array}{l}\text { CESifo World Economic Survey } \\
\text { November } 2015\end{array}$ \\
\hline Research institute & 0.27 & 0.44 & 0 & 1 & 260 & $\begin{array}{l}\text { CESifo World Economic Survey } \\
\text { November } 2015\end{array}$ \\
\hline Other institutions & 0.04 & 0.19 & 0 & 1 & 260 & $\begin{array}{l}\text { CESifo World Economic Survey } \\
\text { November } 2015\end{array}$ \\
\hline
\end{tabular}


Table 3: Correlations (full sample)

\begin{tabular}{|c|c|c|c|c|c|c|c|c|}
\hline & Q1 & Q2 & Q3 & Q4 & Debt-GDP & $\begin{array}{l}\text { Primary Surplus- } \\
\text { to- GDP }\end{array}$ & EF Index & Inc. \\
\hline Q1: Grexit in June & 1.00 & & & & & & & \\
\hline $\begin{array}{l}\text { Q2: Grexit in } \\
\text { October }\end{array}$ & $0.72 * * *$ & 1.00 & & & & & & \\
\hline Q3: IMF credit & $-0.20 * * *$ & $-0.25 * * *$ & 1.00 & & & & & \\
\hline Q4: IMF reforms & $-0.09 *$ & $-0.16 * * *$ & $0.34 * * *$ & 1.00 & & & & \\
\hline Debt-to-GDP & -0.04 & $-0.09 * *$ & 0.00 & 0.01 & 1.00 & & & \\
\hline $\begin{array}{l}\text { Primary Surplus- } \\
\text { to-GDP }\end{array}$ & -0.02 & 0.04 & 0.04 & $0.08 *$ & $-0.35 * * *$ & 1.00 & & \\
\hline EF Index & 0.01 & 0.01 & -0.02 & 0.06 & $0.16^{* * *}$ & $0.16^{* * *}$ & 1.00 & \\
\hline Income Group & -0.06 & -0.03 & 0.01 & 0.02 & $-0.31 * * *$ & 0.05 & $-0.57 * * *$ & 1.00 \\
\hline
\end{tabular}

Table 4: Correlations (Eurozone sample)

\begin{tabular}{lccccccc}
\hline & Q1 & Q2 & Q3 & Q4 & Debt-GDP & $\begin{array}{l}\text { Primary Surplus- } \\
\text { to- GDP Index }\end{array}$ \\
\hline Q1: Grexit in June & 1.00 & & & & & \\
Q2: Grexit in October & $0.74^{* * *}$ & 1.00 & & & & \\
Q3: IMF credit & $-0.29^{* * *}$ & $-0.34^{* * *}$ & 1.00 & & & \\
Q4: IMF reforms & -0.09 & -0.12 & $0.32^{* * *}$ & 1.00 & & \\
Debt-to-GDP & $-0.20^{* * *}$ & $-0.15^{*}$ & $0.13^{*}$ & 0.02 & 1.00 & \\
Primary Surplus-to-GDP & 0.08 & $0.12^{*}$ & 0.02 & 0.04 & 0.04 & 1.00 & \\
EF Index & $0.16^{*}$ & $0.16^{*}$ & -0.06 & 0.11 & $-0.52^{* * *}$ & $0.24^{* * *}$ & 1.00 \\
\hline
\end{tabular}

$* \mathrm{p}<0.10, * * \mathrm{p}<0.05, * * * \mathrm{p}<0.01$ 
Table 5: Regression results (marginal effects) - Grexit in June/July 2015

\begin{tabular}{|c|c|c|c|c|}
\hline & $(1)$ & $(2)$ & (3) & (4) \\
\hline & \multicolumn{2}{|c|}{ Full sample } & \multicolumn{2}{|c|}{ Eurozone sample } \\
\hline Debt-to-GDP & $\begin{array}{c}-0.0005 \\
(-1.20)\end{array}$ & $\begin{array}{c}-0.0009^{* *} \\
(-2.06)\end{array}$ & $\begin{array}{c}-0.0038^{* * *} \\
(-3.86)\end{array}$ & $\begin{array}{c}-0.0035^{* * *} \\
(-2.97)\end{array}$ \\
\hline Primary Surplus-to-GDP & & $\begin{array}{c}-0.0072 \\
(-0.93)\end{array}$ & & $\begin{array}{c}0.0243 \\
(1.50)\end{array}$ \\
\hline EF Index & & $\begin{array}{c}-0.0082 \\
(-0.29)\end{array}$ & & $\begin{array}{c}0.1170 \\
(0.80)\end{array}$ \\
\hline Income Group & & $\begin{array}{c}-0.0747^{* *} \\
(-2.00)\end{array}$ & & \\
\hline Affiliation & & & & \\
\hline Association/Chamber & $\begin{array}{c}-0.0554 \\
(-0.95)\end{array}$ & $\begin{array}{c}-0.0461 \\
(-0.76)\end{array}$ & $\begin{array}{c}-0.0055 \\
(-0.05)\end{array}$ & $\begin{array}{c}-0.0344 \\
(-0.33)\end{array}$ \\
\hline Central Bank & $\begin{array}{c}-0.1630^{*} \\
(-1.94)\end{array}$ & $\begin{array}{c}-0.1240 \\
(-1.33)\end{array}$ & $\begin{array}{c}0.0874 \\
(0.39)\end{array}$ & $\begin{array}{c}0.0617 \\
(0.27)\end{array}$ \\
\hline Financial institution & $\begin{array}{c}-0.0139 \\
(-0.25)\end{array}$ & $\begin{array}{c}-0.0048 \\
(-0.08)\end{array}$ & $\begin{array}{c}-0.0925 \\
(-1.01)\end{array}$ & $\begin{array}{c}-0.1410 \\
(-1.60)\end{array}$ \\
\hline Non-financial company & $\begin{array}{c}0.0424 \\
(0.96)\end{array}$ & $\begin{array}{c}0.0547 \\
(1.20)\end{array}$ & $\begin{array}{c}0.0631 \\
(0.76)\end{array}$ & $\begin{array}{c}0.0266 \\
(0.31)\end{array}$ \\
\hline National ministry/agency & $\begin{array}{c}-0.0175 \\
(-0.23)\end{array}$ & $\begin{array}{r}0.0147 \\
(0.18)\end{array}$ & $\begin{array}{c}0.0819 \\
(0.50)\end{array}$ & $\begin{array}{c}0.0935 \\
(0.56)\end{array}$ \\
\hline Embassy/consulate & $\begin{array}{c}0.2170^{* *} \\
(2.26)\end{array}$ & $\begin{array}{c}0.2110^{* *} \\
(2.16)\end{array}$ & $\begin{array}{c}0.0794 \\
(0.36)\end{array}$ & $\begin{array}{l}0.0750 \\
(0.33)\end{array}$ \\
\hline International organization & $\begin{array}{c}0.00169 \\
(0.02)\end{array}$ & $\begin{array}{c}0.0326 \\
(0.27)\end{array}$ & $\begin{array}{c}0.0944 \\
(0.29)\end{array}$ & $\begin{array}{c}0.1120 \\
(0.34)\end{array}$ \\
\hline Other institutions & $\begin{array}{c}0.1670^{* *} \\
(2.06)\end{array}$ & $\begin{array}{c}0.1870^{* *} \\
(2.29)\end{array}$ & $\begin{array}{c}0.2830^{*} \\
(1.66)\end{array}$ & $\begin{array}{c}0.2470 \\
(1.39)\end{array}$ \\
\hline$N$ & 867 & 834 & 260 & 260 \\
\hline R-squared (adj.) & 0.0150 & 0.0188 & 0.0521 & 0.0634 \\
\hline
\end{tabular}

Dependent variable: Grexit in June/July 2015 (0-no; 1-yes)

Probit-model; z-statistics in parentheses; ${ }^{*} p<0.10,{ }^{* *} p<0.05,{ }^{* * * *} p<0.01$ 
Table 6: Regression results (marginal effects) - Grexit in October

\begin{tabular}{|c|c|c|c|c|}
\hline & $(1)$ & (2) & (3) & (4) \\
\hline & \multicolumn{2}{|c|}{ Full sample } & \multicolumn{2}{|c|}{ Eurozone sample } \\
\hline Debt-to-GDP & $\begin{array}{c}-0.0012^{* * *} \\
(-3.01)\end{array}$ & $\begin{array}{c}-0.0014^{* * *} \\
(-3.05)\end{array}$ & $\begin{array}{c}-0.0028^{* * *} \\
(-3.19)\end{array}$ & $\begin{array}{c}-0.0023^{* *} \\
(-2.20)\end{array}$ \\
\hline Primary Surplus-to-GDP & & $\begin{array}{c}-0.0003 \\
(-0.04)\end{array}$ & & $\begin{array}{r}0.0290^{*} \\
(1.94)\end{array}$ \\
\hline EF Index & & $\begin{array}{c}-0.0115 \\
(-0.42)\end{array}$ & & $\begin{array}{c}0.1540 \\
(1.27)\end{array}$ \\
\hline Income Group & & $\begin{array}{c}-0.0526 \\
(-1.47)\end{array}$ & & \\
\hline Affiliation & & & & \\
\hline Association/Chamber & $\begin{array}{c}-0.0508 \\
(-0.93)\end{array}$ & $\begin{array}{c}-0.0396 \\
(-0.70)\end{array}$ & $\begin{array}{c}0.0012 \\
(0.01)\end{array}$ & $\begin{array}{c}-0.0376 \\
(-0.42)\end{array}$ \\
\hline Central Bank & $\begin{array}{c}-0.1910^{* * *} \\
(-2.89)\end{array}$ & $\begin{array}{c}-0.1620^{* *} \\
(-2.14)\end{array}$ & $\begin{array}{c}-0.1060 \\
(-0.61)\end{array}$ & $\begin{array}{c}-0.1250 \\
(-0.81)\end{array}$ \\
\hline Financial institution & $\begin{array}{c}0.0471 \\
(0.86)\end{array}$ & $\begin{array}{c}0.0601 \\
(1.05)\end{array}$ & $\begin{array}{c}-0.0583 \\
(-0.69)\end{array}$ & $\begin{array}{c}-0.1140 \\
(-1.49)\end{array}$ \\
\hline Non-financial company & $\begin{array}{c}0.0622 \\
(1.46)\end{array}$ & $\begin{array}{c}0.0717 \\
(1.63)\end{array}$ & $\begin{array}{c}0.0989 \\
(1.26)\end{array}$ & $\begin{array}{c}0.0472 \\
(0.60)\end{array}$ \\
\hline National ministry/agency & $\begin{array}{c}-0.0429 \\
(-0.62)\end{array}$ & $\begin{array}{c}-0.0351 \\
(-0.49)\end{array}$ & $\begin{array}{c}0.0188 \\
(0.12)\end{array}$ & $\begin{array}{c}0.0282 \\
(0.18)\end{array}$ \\
\hline Embassy/consulate & $\begin{array}{c}0.1610 \\
(1.64)\end{array}$ & $\begin{array}{c}0.1550 \\
(1.54)\end{array}$ & $\begin{array}{c}0.1910 \\
(0.86)\end{array}$ & $\begin{array}{c}0.1820 \\
(0.77)\end{array}$ \\
\hline International organization & $\begin{array}{c}-0.0164 \\
(-0.16)\end{array}$ & $\begin{array}{c}0.0016 \\
(0.01)\end{array}$ & & \\
\hline Other institutions & $\begin{array}{c}0.0965 \\
(1.22)\end{array}$ & $\begin{array}{c}0.1200 \\
(1.47)\end{array}$ & $\begin{array}{c}0.1980 \\
(1.11)\end{array}$ & $\begin{array}{c}0.1370 \\
(0.80)\end{array}$ \\
\hline$N$ & 863 & 830 & 256 & 256 \\
\hline R-squared (adj.) & 0.0217 & 0.0240 & 0.0401 & 0.0623 \\
\hline
\end{tabular}

Dependent variable: Grexit in October 2015 (0-no; 1-yes)

Probit-model; z-statistics in parentheses; ${ }^{*} p<0.10,{ }^{* *} p<0.05,{ }^{* * *} p<0.01$ 
Table 7: Regression results (marginal effects) - IMF credit

\begin{tabular}{|c|c|c|c|c|}
\hline & $(1)$ & $(2)$ & (3) & $(4)$ \\
\hline & \multicolumn{2}{|c|}{ Full sample } & \multicolumn{2}{|c|}{ Eurozone sample } \\
\hline Debt-to-GDP & $\begin{array}{c}0.0001 \\
(0.18)\end{array}$ & $\begin{array}{c}0.0003 \\
(0.67)\end{array}$ & $\begin{array}{c}0.0023^{* *} \\
(2.48)\end{array}$ & $\begin{array}{c}0.0021^{*} \\
(1.87)\end{array}$ \\
\hline Primary Surplus-to-GDP & & $\begin{array}{c}0.0107 \\
(1.45)\end{array}$ & & $\begin{array}{c}0.0001 \\
(0.00)\end{array}$ \\
\hline EF Index & & $\begin{array}{c}-0.0146 \\
(-0.51)\end{array}$ & & $\begin{array}{c}-0.0740 \\
(-0.61)\end{array}$ \\
\hline Income Group & & $\begin{array}{c}0.0007 \\
(0.02)\end{array}$ & & \\
\hline Affiliation & & & & \\
\hline Association/Chamber & $\begin{array}{c}-0.0094 \\
(-0.16)\end{array}$ & $\begin{array}{c}-0.0218 \\
(-0.37)\end{array}$ & $\begin{array}{c}-0.0703 \\
(-0.66)\end{array}$ & $\begin{array}{c}-0.0691 \\
(-0.65)\end{array}$ \\
\hline Central Bank & $\begin{array}{c}-0.1310 \\
(-1.32)\end{array}$ & $\begin{array}{c}-0.1340 \\
(-1.28)\end{array}$ & $\begin{array}{c}-0.2770 \\
(-1.27)\end{array}$ & $\begin{array}{c}-0.2810 \\
(-1.28)\end{array}$ \\
\hline Financial institution & $\begin{array}{c}0.0594 \\
(1.21)\end{array}$ & $\begin{array}{c}0.0531 \\
(1.05)\end{array}$ & $\begin{array}{c}0.0695 \\
(0.82)\end{array}$ & $\begin{array}{c}0.0751 \\
(0.88)\end{array}$ \\
\hline Non-financial company & $\begin{array}{c}-0.0514 \\
(-1.23)\end{array}$ & $\begin{array}{c}-0.0606 \\
(-1.41)\end{array}$ & $\begin{array}{r}-0.1420^{*} \\
(-1.79)\end{array}$ & $\begin{array}{c}-0.1380^{*} \\
(-1.73)\end{array}$ \\
\hline National ministry/agency & $\begin{array}{c}0.0459 \\
(0.69)\end{array}$ & $\begin{array}{c}0.0355 \\
(0.51)\end{array}$ & $\begin{array}{c}-0.4400^{* * * *} \\
(-3.04)\end{array}$ & $\begin{array}{c}-0.4510^{* * *} \\
(-3.19)\end{array}$ \\
\hline Embassy/consulate & $\begin{array}{c}0.0680 \\
(0.85)\end{array}$ & $\begin{array}{c}0.0592 \\
(0.73)\end{array}$ & $\begin{array}{c}-0.2420 \\
(-1.07)\end{array}$ & $\begin{array}{c}-0.2300 \\
(-0.99)\end{array}$ \\
\hline International organization & $\begin{array}{c}0.0034 \\
(0.03)\end{array}$ & $\begin{array}{c}0.0165 \\
(0.16)\end{array}$ & & \\
\hline Other institutions & $\begin{array}{c}0.0938 \\
(1.47) \\
\end{array}$ & $\begin{array}{c}0.0875 \\
(1.35) \\
\end{array}$ & & \\
\hline$N$ & 846 & 814 & 251 & 251 \\
\hline R-squared (adj.) & 0.0104 & 0.0124 & 0.0666 & 0.0676 \\
\hline
\end{tabular}

Dependent variable: IMF credit (0-no; 1-yes)

Probit-model; z-statistics in parentheses; ${ }^{*} p<0.10,{ }^{* *} p<0.05,{ }^{* * *} p<0.01$ 
Table 8: Regression results (marginal effects) - IMF reform

\begin{tabular}{|c|c|c|c|c|}
\hline & (1) & (2) & (3) & (4) \\
\hline & \multicolumn{2}{|c|}{ Full sample } & \multicolumn{2}{|c|}{ Eurozone sample } \\
\hline Debt-to-GDP & $\begin{array}{c}0.0001 \\
(0.13)\end{array}$ & $\begin{array}{c}0.0002 \\
(0.69)\end{array}$ & $\begin{array}{c}0.0001 \\
(0.11)\end{array}$ & $\begin{array}{c}0.0008 \\
(0.94)\end{array}$ \\
\hline Primary Surplus-to-GDP & & $\begin{array}{r}0.0103^{*} \\
(1.72)\end{array}$ & & $\begin{array}{c}-0.0064 \\
(-0.63)\end{array}$ \\
\hline EF Index & & $\begin{array}{c}0.0395^{*} \\
(1.76)\end{array}$ & & $\begin{array}{c}0.1590 \\
(1.64)\end{array}$ \\
\hline Income Group & & $\begin{array}{c}0.0305 \\
(1.06)\end{array}$ & & \\
\hline Affiliation & & & & \\
\hline Association/Chamber & $\begin{array}{c}0.0513 \\
(1.35)\end{array}$ & $\begin{array}{r}0.0377 \\
(0.94)\end{array}$ & $\begin{array}{c}0.0784 \\
(1.55)\end{array}$ & $\begin{array}{c}0.0792 \\
(1.62)\end{array}$ \\
\hline Central Bank & $\begin{array}{c}0.0848^{*} \\
(1.72)\end{array}$ & $\begin{array}{l}0.0685 \\
(1.23)\end{array}$ & & \\
\hline Financial institution & $\begin{array}{c}0.0270 \\
(0.71)\end{array}$ & $\begin{array}{c}0.0297 \\
(0.78)\end{array}$ & $\begin{array}{c}0.1080^{* *} \\
(2.51)\end{array}$ & $\begin{array}{c}0.1030^{* *} \\
(2.32)\end{array}$ \\
\hline Non-financial company & $\begin{array}{c}0.0511^{*} \\
(1.73)\end{array}$ & $\begin{array}{c}0.0430 \\
(1.41)\end{array}$ & $\begin{array}{c}0.0588 \\
(1.21)\end{array}$ & $\begin{array}{c}0.0505 \\
(1.02)\end{array}$ \\
\hline National ministry/agency & $\begin{array}{c}0.1060^{* * * *} \\
(2.95)\end{array}$ & $\begin{array}{c}0.1030^{* * *} \\
(2.86)\end{array}$ & $\begin{array}{c}0.0847 \\
(1.29)\end{array}$ & $\begin{array}{c}0.0955 \\
(1.61)\end{array}$ \\
\hline Embassy/consulate & $\begin{array}{c}0.0352 \\
(0.59)\end{array}$ & $\begin{array}{c}0.0394 \\
(0.68)\end{array}$ & $\begin{array}{c}0.0023 \\
(0.02)\end{array}$ & $\begin{array}{c}-0.0175 \\
(-0.12)\end{array}$ \\
\hline International organization & $\begin{array}{c}-0.0151 \\
(-0.19)\end{array}$ & $\begin{array}{c}-0.0073 \\
(-0.09)\end{array}$ & & \\
\hline Other institutions & $\begin{array}{c}0.1170^{* * * *} \\
(3.39)\end{array}$ & $\begin{array}{c}0.1150^{* * *} \\
(3.42)\end{array}$ & & \\
\hline$N$ & 851 & 819 & 252 & 252 \\
\hline R-squared (adj.) & 0.0152 & 0.0266 & 0.0249 & 0.0432 \\
\hline
\end{tabular}

Dependent variable: IMF reform (0-no; 1-yes)

Probit-model; z-statistics in parentheses; ${ }^{*} p<0.10,{ }^{* *} p<0.05,{ }^{* * *} p<0.01$ 